\title{
REHABILITATION IN PALLIATIVE CARE
}

\author{
Jéssica Sponton Moura Minosso', Luciene Jacinto de Souza², Maria Amélia de Campos Oliveira ${ }^{3}$
}

\footnotetext{
${ }^{1}$ Doctoral student. Programa Interunidades de Doutoramento em Enfermagem, Escola de Enfermagem and Escola de Enfermagem de Ribeirão Preto, Universidade de São Paulo. São Paulo, São Paulo, Brazil. E-mail: jessica.minosso@usp.br

${ }^{2}$ Master's student. Programa de Pós-Graduação em Enfermagem, Escola de Enfermagem da USP. CAPES Scholarship student. São Paulo, São Paulo, Brazil. E-mail: luciene.jacinto@usp.br

${ }^{3}$ Ph.D. in Nursing. Professor. Departamento de Enfermagem em Saúde Coletiva, Escola de Enfermagem. USP. São Paulo, São Paulo, Brazil. E-mail: macampos@usp.br
}

\begin{abstract}
The objective of this study was to describe the activities and effects of functional rehabilitation in patients receiving palliative care. It is an integrative review, in which LILACS, BDENF, Coleciona SUS (Brazil) and PUBMED were used, 20 articles were selected, subsequently characterized as having designs of medium and low impact, more than half ranked with evidence levels II, III and IV and with samples not always consistent with the research designs. However, the results revealed the potential of rehabilitation to improve the functional status, quality of life and symptoms like pain and anxiety in this population, through interventions that are many times undervalued in palliative care. The conclusion is that rehabilitation is a feasible strategy to combat functional decline and improve the quality of life of patients in palliative care.
\end{abstract}

DESCRIPTORS: Palliative care. Activities of daily living. Rehabilitation.

\section{REABILITAÇÃO EM CUIDADOS PALIATIVOS}

RESUMO: O objetivo deste estudo foi descrever as atividades e os efeitos da reabilitação funcional em pacientes que recebem cuidados paliativos. Trata-se de uma revisão integrativa que utilizou as bases de dados LILACS, BDENF, Coleciona SUS (Brasil) e PubMed. Foram selecionados 20 artigos, posteriormente caracterizados como de desenhos de médio e baixo impacto, sendo que mais da metade foi classificada com níveis de evidência II, III e IV e amostras nem sempre condizentes com os desenhos de pesquisa. Porém, os resultados revelaram o potencial da reabilitação para melhoria do estado funcional, da qualidade de vida e sintomas como dor e ansiedade nessa população, por meio de intervenções muitas vezes subvalorizadas em cuidados paliativos. Conclui-se que a reabilitação é uma estratégia viável para combater o declínio funcional e melhorar a qualidade de vida de pacientes em cuidados paliativos.

DESCRITORES: Cuidados paliativos. Atividades cotidianas. Reabilitação.

\section{REHABILITACIÓN EN CUIDADOS PALIATIVOS}

RESUMEN: El objetivo de este estudio fue describir las actividades y los efectos de la rehabilitación funcional en pacientes que reciben cuidados paliativos. Es una revisión integradora que utiliza las bases de datos LILACS, BDENF, Coleciona SUS (Brasil) y PUBMED. Se seleccionaron 20 artículos, después caracterizados con diseños de mediano y bajo impacto, y más de la mitad se clasificó con niveles de evidencia II, III, IV y con muestras no siempre consistentes con los diseños de investigación. Todavía, los resultados revelaran el potencial de la rehabilitación para mejorar el estado funcional, la calidad de vida y los síntomas como dolor y ansiedad en esta población, a través de intervenciones muchas veces infravaloradas en cuidados paliativos. Se concluye que la rehabilitación es una estrategia viable para combatir el deterioro funcional y mejorar la calidad de vida de los pacientes en cuidados paliativos.

DESCRIPTORES: Cuidados paliativos. Actividades cotidianas. Rehabilitación. 


\section{INTRODUCTION}

According to the World Health Organization (WHO), palliative care (PC) is "an approach that improves the quality of life of patients and their families facing the problem associated with lifethreatening illness, through the prevention and relief of suffering by means of early identification and impeccable assessment and treatment of pain and other problems, physical, psychosocial and spiritual". 1:14 Rehabilitation interventions are an important strategy for this approach, as the functional decline results in losses in the performance of daily living activities and in the ability to attend to health needs.

The loss of functionality accompanies the trajectory of most life-threatening illnesses, in addition to the profound physical, emotional and spiritual changes that patients experience as from the diagnosis and until they die. This condition is always heterogeneous, varying with the disease and its progression, with age, comorbidities, the therapeutics used and the physical, emotional, spiritual and social condition of each patient. Therefore, research and investigation are fundamental to attend to the needs of these people and their families. ${ }^{2-3}$

It is essential for health professionals to be qualified to offer specialized and structured support to PC patients and their families, attempting to profoundly understand the impact the disease produces. Among all potential sources of suffering for the patients, the loss of autonomy can be considered one of the most important. ${ }^{4}$ The caregiver's burden, the institutionalization and the greater use of health system resources are direct consequences of the functional decline and the lack of effective interventions to promote autonomy of patients in PC. ${ }^{5}$

The concept of rehabilitation in PC has been progressively established in the academic context and in health care services. One desire PC patients frequently express is to remain physically independent until the end of their life. ${ }^{2,5}$ Executing the activities of daily living and maintaining mobility are areas for intervention that result in significant gains in terms of quality of life. The effect of rehabilitation interventions can be expanded beyond the physical dimension, like beneficial changes in the family dynamics for example, through the reduction in the caregivers and families' burden. Appropriate knowledge on rehabilitation is fundamental to deliver integral and comprehensive care to patients with incurable diseases. ${ }^{5}$

Thus, the objective in this study was to describe the activities and effects of functional rehabilitation in PC patients, through an integrative literature review.

\section{METHOD}

An integrative review was undertaken, a review modality that uses a comprehensive method, which permits the analysis of studies with different quantitative or qualitative research designs and experimental and non-experimental approaches. ${ }^{6}$ The investigation was developed in six phases: identification of the problem, literature review, ranking of the studies, analysis of the studies, interpretation of the results and synthesis of the review findings.$^{7-8}$

The guiding question was: what are the results of functional rehabilitation in adult palliative care patients? To answer the question, the PICO strategy was used, in which the population $(\mathrm{P})$ consisted of adult palliative care patients, the intervention (I) or independent variable of interest was the functional rehabilitation, the comparison (C) or dependent variable was the functional status and the outcomes (O) were the effects of the rehabilitation. ${ }^{9}$

The search for the articles was undertaken in the databases Latin-American and Caribbean Health Sciences Literature (LILACS), Nursing Database (BDENF) and Coleciona SUS (Brazil), through the research portal of the Virtual Health Library (BVS), and the National Library of Medicine (PubMed). Two researchers selected the articles independently. In case of disagreement, a joint and exhaustive reanalysis of the respective studies permitted reaching a consensus in the composition of the final sample.

The descriptors used in the databases, in Portuguese, English and Spanish, were: Rehabilitation, Palliative Care, Activities of Daily Living, Disability and Recovery of Function, according to the Medical Subject Heading (MeSH) terminology of the National Library of Medicine and the Health Sciences Descriptors (DeCS) of the Virtual Health Library (BVS). The data were collected between July and November 2014. 
The criteria for inclusion in the study were: articles published in the last five years, in which the rehabilitation interventions and their outcomes were assessed in adult PC patients; with the abstract and full text available online; written in English,
Portuguese or Spanish. Studies involving patients with cognitive problems and whose content did not respond to the guiding question in this study were excluded. The search strategy used and the respective outcomes are displayed in table 1.

Table 1 - Results of literature search in the databases. São Paulo, SP, Brazil, 2015

\begin{tabular}{|l|r|r|r|r|r|}
\hline \multicolumn{1}{|c|}{ Descriptors/s } & PubMed & LILACS & BDENF & Coleciona SUS & Total \\
\hline Rehabilitation AND palliative care & 397 & 7 & - & - & 404 \\
\hline Disability AND palliative care & 68 & 1 & - & - & 69 \\
\hline Daily living activities AND palliative care & 113 & - & - & - & 113 \\
\hline Recovery of function AND palliative care & 19 & - & - & - & 19 \\
\hline
\end{tabular}

The studies were selected in accordance with the PRISMA (Preferred Reporting Items for Systematic Review and Meta-Analyses) criteria. ${ }^{10}$ The results obtained in each phase have been summarized in the flowchart in figure 1.

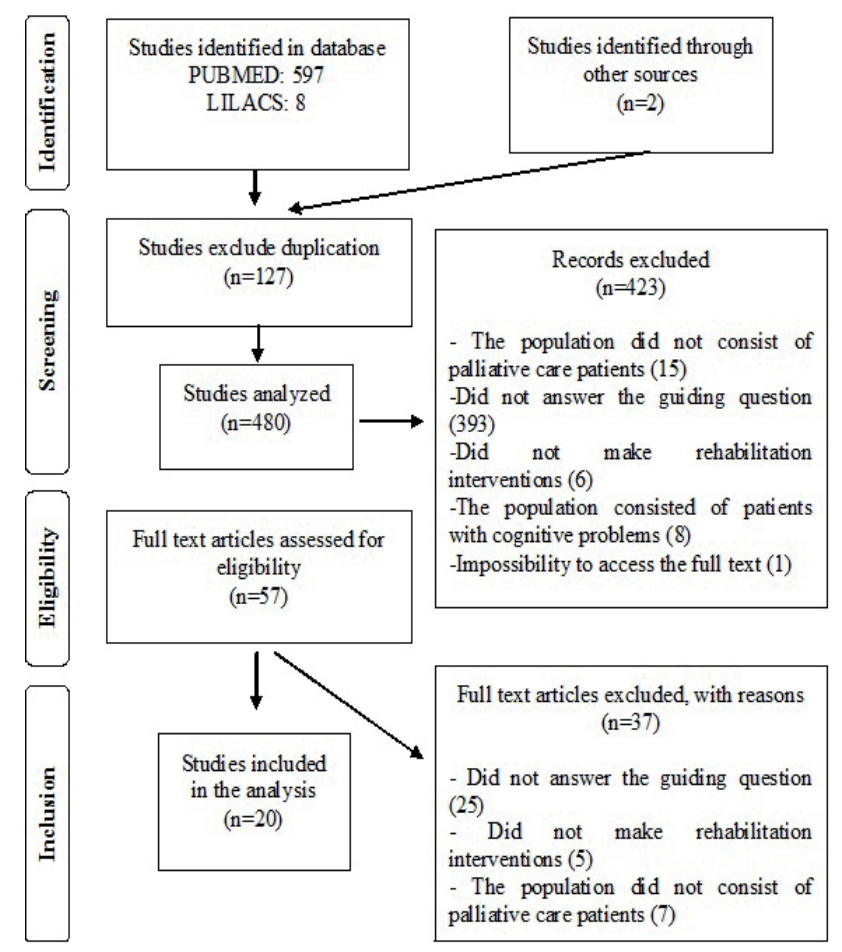

Figure 1 - Flowchart of selected studies. São Paulo, SP, Brazil, 2015

Out of 597 articles found in the database PubMed, 20 were selected after the exclusion of duplicated articles and the reading of the abstracts and full texts. In LILACS, eight articles were located, but later discarded because they did not comply with the inclusion criteria. Two articles were selected through citations but excluded for the same reason. Thus, the study sample consisted of 20 articles.

To collect the data was utilized an instrument submitted to content validation by two experts, ${ }^{8}$ who were college teachers experienced in reviews, whose suggestions were adopted. The tool includes: identification of the article, journal and authors, method used, interventions and conclusions. Next, the analysis started to identify the functional rehabilitation outcomes of PC patients. Particularly the conclusions and implications of the functional rehabilitation interventions were analyzed in detail. The evidence level was classified according to the National Cancer Institute: Levels of Evidence for Supportive and Palliative Care Studies (PDQ $\left.{ }^{\circledR}\right) .{ }^{11}$

Two tables were produced to present the results, the first displaying the characteristics of the studies and the second showing the type of intervention used and the conclusion. In the discussion, the results of the selected studies were integrated to build a general concept of rehabilitation in PC.

\section{RESULTS}

Table 2, about the study characteristics, displays information on the authors, country of origin of the research, place and year of study, methodological design and sample size. 
Table 2 - Characterization of scientific production on rehabilitation in palliative care in adults. São Paulo, SP, Brazil, 2015

\begin{tabular}{|c|c|c|c|}
\hline Authors & $\begin{array}{c}\text { Year } \\
\text { Country }\end{array}$ & Place & Design (sample) \\
\hline Buss $\mathrm{T}^{12}$ & $\begin{array}{c}2009 \\
\text { Poland }\end{array}$ & Home and hospice & Quasi-experimental study $(\mathrm{n}=49)$ \\
\hline Cheville $\mathrm{AL}^{13}$ & $\begin{array}{l}2013 \\
\text { USA }\end{array}$ & Home & Randomized clinical trial $(\mathrm{n}=66)$ \\
\hline Clemens KE ${ }^{14}$ & $\begin{array}{c}2010 \\
\text { Germany }\end{array}$ & Hospital & Retrospective study $(\mathrm{n}=90)$ \\
\hline Granda-Cameron, $\mathrm{C}^{15}$ & $\begin{array}{l}2010 \\
\text { USA }\end{array}$ & Clinic & Longitudinal study $(\mathrm{n}=11)$ \\
\hline Gulde $I^{16}$ & $\begin{array}{c}2011 \\
\text { Sweden }\end{array}$ & - & Qualitative study $(\mathrm{n}=11)$ \\
\hline Guo $Y^{17}$ & $\begin{array}{l}2011 \\
\text { USA }\end{array}$ & Clinic & Retrospective study $(n=60)$ \\
\hline Henke $\mathrm{CC}^{18}$ & $\begin{array}{c}2013 \\
\text { Germany } \\
\end{array}$ & Hospital & Randomized clinical trial $(n=46)$ \\
\hline Javier NS 5 & $\begin{array}{l}2011 \\
\text { USA }\end{array}$ & University & Literature review \\
\hline Jensen $\mathrm{W}^{19}$ & $\begin{array}{c}2014 \\
\text { Germany }\end{array}$ & Clinic & Pretest/posttest design with control group $(n=26)$ \\
\hline Jensen $W^{20}$ & $\begin{array}{c}2014 \\
\text { Germany }\end{array}$ & Clinic & Retrospective study $(n=572)$ \\
\hline Jones L ${ }^{21}$ & $\begin{array}{c}2013 \\
\text { England }\end{array}$ & Clinic and home & Randomized clinical trial $(n=41)$ \\
\hline Kasven-Gonzalez $\mathrm{N}^{22}$ & $\begin{array}{l}2010 \\
\text { USA }\end{array}$ & Hospital & Case study $(\mathrm{n}=1)$ \\
\hline Litterini $\mathrm{AJ}^{23}$ & $\begin{array}{l}2013 \\
\text { USA }\end{array}$ & $\begin{array}{c}\text { Community center and } \\
\text { hospital }\end{array}$ & Pretest/posttest design with control group $(n=52)$ \\
\hline Maddocks $\mathrm{M}^{24}$ & $\begin{array}{c}2013 \\
\text { England }\end{array}$ & Research center & Systematic review $(n=11)$ \\
\hline Oechsle $\mathrm{K}^{25}$ & $\begin{array}{c}2011 \\
\text { Germany }\end{array}$ & Clinic & Cross-sectional study $(n=53)$ \\
\hline Oldervoll LM ${ }^{26}$ & $\begin{array}{c}2011 \\
\text { Norway }\end{array}$ & University & Randomized clinical trial $(\mathrm{n}=231)$ \\
\hline Saarik J J7 & $\begin{array}{c}2010 \\
\text { England }\end{array}$ & Hospice & Longitudinal study $(\mathrm{n}=28)$ \\
\hline Selman LE ${ }^{28}$ & $\begin{array}{c}2011 \\
\text { England }\end{array}$ & Hospice & Quasi-experimental study $(\mathrm{n}=18)$ \\
\hline Sturm I ${ }^{29}$ & $\begin{array}{c}2014 \\
\text { Germany } \\
\end{array}$ & Hospital & Quasi-experimental study $(\mathrm{n}=40)$ \\
\hline van Dam van Isselt $\mathrm{EF}^{30}$ & $\begin{array}{c}2013 \\
\text { Holland }\end{array}$ & Assisted living home & Case study $(n=3)$ \\
\hline
\end{tabular}

As for the countries of origin, $70 \%$ of the studies were developed in European countries, and the remainder in the United States of America (USA). Concerning the sample size, the samples were small and not always in accordance with the research designs, ranging between one and 572 participants. Most studies were developed at clinics with multiprofessional teams. Table 3 displays the rehabilitation interventions, the outcomes of their use and the classification of the studies in terms of evidence level. 
Table 3 - Outcomes of studies and classification of evidence level according to National Cancer Institute: Levels of Evidence for Supportive and Palliative Care Studies (PDQ®). São Paulo, SP, Brazil, 2015

\begin{tabular}{|c|c|c|c|}
\hline Authors & Interventions & Outcomes & $\begin{array}{c}\text { Evidence } \\
\text { level }\end{array}$ \\
\hline Buss T $^{12}$ & Kinesiotherapy & Reduced intensity of fatigue. & II \\
\hline Cheville $\mathrm{AL}^{13}$ & $\begin{array}{l}\text { Domestic exercise } \\
\text { program involving } \\
\text { walks and strength } \\
\text { training }\end{array}$ & $\begin{array}{l}\text { Improvements in mobility, fatigue and sleep quality of } \\
\text { patients in stage IV of lung and colorectal cancer. }\end{array}$ & I \\
\hline Clemens $\mathrm{KE}^{14}$ & Lymphatic drainage & $\begin{array}{l}\text { Most patients demonstrated improvements in the inten- } \\
\text { sity of the symptoms (pain and dyspnea) after manual } \\
\text { lymphatic drainage. }\end{array}$ & III \\
\hline Granda-Cameron $\mathrm{C}^{15}$ & $\begin{array}{l}\text { Multidisciplinary } \\
\text { program }\end{array}$ & $\begin{array}{l}\text { Weight gain, increase in body cell mass indicator and re- } \\
\text { duction of symptom load. }\end{array}$ & II \\
\hline Gulde ${ }^{16}$ & $\begin{array}{c}\text { Physical exercise } \\
\text { guided by physio- } \\
\text { therapist }\end{array}$ & $\begin{array}{l}\text { Structuring of routine, reduction of feeling of fatigue, in- } \\
\text { creased feeling of bodily control, increased hope. }\end{array}$ & III \\
\hline Guo $Y^{17}$ & $\begin{array}{l}\text { Physiotherapy, oc- } \\
\text { cupational therapy, } \\
\text { speech, language and } \\
\text { hearing therapy and } \\
\text { rehabilitation nurs- } \\
\text { ing interventions } \\
\end{array}$ & $\begin{array}{l}\text { Asthenic patients in inpatient regimen with solid tumors } \\
\text { or hematological cancer can obtain rehabilitation benefits } \\
\text { and reach significant functional gain. }\end{array}$ & III \\
\hline Henke $\mathrm{CC}^{18}$ & $\begin{array}{l}\text { Additional strength } \\
\text { and resistance train- } \\
\text { ing }\end{array}$ & $\begin{array}{l}\text { The training positively affected the functionality, resis- } \\
\text { tance and strength, demonstrating that even patients in } \\
\text { palliative chemotherapy should receive interventions } \\
\text { that increase the physical activity. }\end{array}$ & $\mathrm{I}$ \\
\hline Javier NS ${ }^{5}$ & $\begin{array}{l}\text { Varying rehabilita- } \\
\text { tion interventions }\end{array}$ & $\begin{array}{l}\text { The studies demonstrated benefits of rehabilitation for } \\
\text { the functional capacity, quality of life, mobility, fatigue, } \\
\text { pain, wellbeing, dyspnea, emotional status and cognitive } \\
\text { function. }\end{array}$ & IV \\
\hline Jensen $W^{19}$ & $\begin{array}{l}\text { Aerobic or resistance } \\
\text { training in group }\end{array}$ & $\begin{array}{l}\text { Aerobic and resistance training was feasible for patients } \\
\text { with gastrointestinal cancer submitted to palliative che- } \\
\text { motherapy. Both training programs produced improve- } \\
\text { ments in cancer-related symptoms, as well as in physical } \\
\text { activities of daily living. }\end{array}$ & I \\
\hline Jensen $W^{20}$ & $\begin{array}{l}\text { Physical exercise or } \\
\text { physiotherapy }\end{array}$ & $\begin{array}{l}\text { Physical exercises and physiotherapy were feasible for } \\
\text { more than } 90 \% \text { of terminal cancer patients. Physical ex- } \\
\text { ercises, relaxation therapy and respiratory training were } \\
\text { the most easily applicable measures. Prospective clinical } \\
\text { trials are needed to assess the efficacy of specific physical } \\
\text { exercise and physiotherapy programs in terminal cancer } \\
\text { patients. }\end{array}$ & III \\
\hline Jones L ${ }^{21}$ & $\begin{array}{l}\text { Rehabilitation exer- } \\
\text { cises at home }\end{array}$ & $\begin{array}{l}\text { The intervention significantly reduced the unattended } \\
\text { needed of cancer survivors, probably with a good cost- } \\
\text { effectiveness relation. The program should be imple- } \\
\text { mented in larger populations, followed by an assessment. }\end{array}$ & I \\
\hline Kasven-Gonzalez N22 & $\begin{array}{l}\text { Physiotherapy and } \\
\text { occupational therapy }\end{array}$ & $\begin{array}{l}\text { Improvements in the perceived quality of life, balance, } \\
\text { strength, mobility and sociability. }\end{array}$ & III \\
\hline Litterini $\mathrm{AJ}^{23}$ & $\begin{array}{l}\text { Resistance or cardio- } \\
\text { vascular exercises }\end{array}$ & $\begin{array}{l}\text { Advanced cancer patients seem to benefit from exercising } \\
\text { to improve their functional mobility. }\end{array}$ & I \\
\hline Maddocks $\mathrm{M}^{24}$ & $\begin{array}{l}\text { Neuromuscular elec- } \\
\text { tric stimulus }\end{array}$ & $\begin{array}{l}\text { Neuromuscular electric stimulus was an effective medium } \\
\text { to reduce muscle weakness in adults with progressive con- } \\
\text { ditions, such as COPD, chronic cardiac diseases and can- } \\
\text { cer. Further research is needed to clarify its place in clinical } \\
\text { practice through the determination of the ideal parameters } \\
\text { for a neuromuscular electric stimulation program. }\end{array}$ & I \\
\hline
\end{tabular}




\begin{tabular}{|c|c|c|c|}
\hline Oechsle $\mathrm{K}^{25}$ & Physical exercises & $\begin{array}{l}\text { Positive and statistically significant correlation between } \\
\text { physical exercise and quality of life. About } 2 / 3 \text { of the crit- } \\
\text { ically ill patients demonstrated interest in participating in } \\
\text { physical exercise programs. }\end{array}$ & II \\
\hline Oldervoll LM ${ }^{26}$ & $\begin{array}{l}\text { Physical exercise } \\
\text { group }\end{array}$ & $\begin{array}{l}\text { The fatigue intensity was not reduced, but the physical } \\
\text { performance improved significantly after eight weeks of } \\
\text { physical exercise. Therefore, physical exercise can be an } \\
\text { appropriate approach to maintain the physical capacity } \\
\text { in cancer patients with advanced stages of incurable dis- } \\
\text { eases. }\end{array}$ & I \\
\hline Saarik J ${ }^{27}$ & $\begin{array}{l}\text { Fatigue management } \\
\text { program }\end{array}$ & Reduction of fatigue intensity. & II \\
\hline Selman LE ${ }^{28}$ & $\begin{array}{l}\text { Yoga and dance } \\
\text { therapy }\end{array}$ & $\begin{array}{l}\text { The results suggest that yoga and dance therapy can ben- } \\
\text { efit PC patients. }\end{array}$ & II \\
\hline Sturm $I^{29}$ & Dance classes & $\begin{array}{l}\text { Dancing can be an appropriate and effective approach to } \\
\text { treat cancer-related fatigue. }\end{array}$ & II \\
\hline van Dam van Isselt $\mathrm{EF}^{30}$ & $\begin{array}{l}\text { Geriatric Rehabilita- } \\
\text { tion Program }\end{array}$ & $\begin{array}{l}\text { Case studies showed that a geriatric rehabilitation pro- } \\
\text { gram for chronic obstructive pulmonary disease (COPD) } \\
\text { can offer substantial benefits as part of PC rehabilitation } \\
\text { aspects. }\end{array}$ & III \\
\hline
\end{tabular}

Most studies were classified under evidence levels II (30\%), III (30\%) and IV (5\%), while level I was attributed to $35 \%$ of the articles. Many interventions involved multiprofessional teams. The articles adopted different perspectives, although all referred to functional rehabilitation and its potential benefits for palliative care patients. The feasibility of rehabilitation in patients beyond possibilities of cure was proven in most cases, with rare exceptions.

\section{DISCUSSION}

Many PC patients experience functional decline, which certainly causes repercussions in different aspects of their lives. Interferences in the ability to execute daily tasks increase the probability of psychological unrest. The functionality loss and the fear of turning into a burden for the caregiver and the family are frequent concerns that are continuously mentioned among the reasons to desire the end of life. ${ }^{31}$

The objective of rehabilitation in PC is to improve the patients' quality of life, helping them to achieve their full physical, psychological, social, vocational and cognitive potential with as little dependence as possible, independently of the life expectancy. To achieve this objective, many elements are highlighted in the studies, such as: setting realistic goals, multidisciplinary teamwork, ability to react rapidly to emerging needs, among others. $5,21,32$
Despite the increased attention to quality of life in PC, the role of rehabilitation continues to arouse doubts as, at first sight, its objectives may seem incompatible with PC. Terminal patients are frequently forced to make important decisions about their health, future, family and possessions and the rehabilitation interventions may seem inappropriate in view of the circumstances. ${ }^{33}$

Nevertheless, an increasing number of studies guarantees that rehabilitation works towards many unsatisfied needs of the PC patients and, although it does not eliminate the damage the diseases cause, it can certainly mitigate them. ${ }^{22,31-34}$ In addition, it seems to unite patients and their families through a common objective, that is, to act against the functional decline so that it is not experienced in a solitary manner, isolated from the family and the health team.

The studies analyzed evidenced the benefits of functional rehabilitation: reduction of symptoms like pain, dyspnea and fatigue; improvement of nutritional and emotional status; muscle strengthening and increased range of movements, balance and feeling of control over the body, resulting in a better quality of life for the patients studied. ${ }^{35-37}$ It can also promote the reduction of stress and positively influence the patient's perceived independence. ${ }^{22}$ Effects of rehabilitation related to the psychosocial sphere, such as anxiety, stress and depression, were also found, as well as the patients' desire to feel physically better, even when they know that death is approaching. ${ }^{35}$ 
The importance of environments with a calm atmosphere was highlighted, with relaxation and confidence to enhance the effects of the interventions. Like in the other situations related to therapeutic interventions, a strong bond with the health professional is also fundamental. ${ }^{38}$

The decisions about treatment in PC are often motivated by quality of life aspects and, on different occasions, the patient's view differs from the professionals' perspective. A recent qualitative study revealed that the symptom load alone does not necessarily affect the quality of life. In fact, it is its relation with the so-called fundamental dimensions of quality of life that does this. One of these dimensions is activity and participation. ${ }^{37}$ The rehabilitation offers many potential contributions to improvements in this domain. Nevertheless, to enhance the probability of success, the health professional needs to take into account the patients' limitations and change the program whenever necessary. ${ }^{22}$

Rehabilitation interventions still are not considered very relevant in PC and could certainly be used in a more frequent and effective manner. Research on rehabilitation in PC remains limited and further studies in the area are needed, with higher evidence levels. Studies are needed that lead to reliable results, such as randomized clinical trials. One of the difficulties mentioned to accomplish such research is the difficulty to establish control groups, as excluding PC patients from potential benefits is a complex task given the short time of life they have left. ${ }^{14}$

\section{CONCLUSION}

Functional decline is a common condition among PC patients. Maintaining the ability to execute activities of daily living is an important objective in this type of care, given its positive implications in the family structure, relationships, work and social life. The studies analyzed demonstrated the role of rehabilitation to achieve these activities and structure the daily life, resulting in a better quality of life.

Reducing the suffering is one of the main targets in PC delivery and rehabilitation is one of the strategies with the greatest potential to achieve this. Some of the potential benefits of rehabilitation include improved mobility, fatigue, pain, dyspnea and emotional status. Treatment should be planned individually and based on the general prognosis and potential for functional recovery, as well as on the patient's desire and motivation to achieve this objective. Many interventions can be used, such as physiotherapy, speech therapy, occupational therapy, among others.

Despite the advantages, the role of rehabilitation in PC still is not prominent for different reasons: lack of coordination in the health team, lack of rehabilitation programs and services at PC facilities and particularly a reduced number of scientific articles registering the improved functional status and quality of life after the rehabilitation interventions.

These study results indicate that functional rehabilitation is a strategy that permits reducing the functional decline and improving the quality of life of PC patients, but highlight the need for experimental and quasi-experimental studies to obtain reliable results and promote safe interventions that result in a better quality of life for this population.

\section{REFERENCES}

1. World Health Organization. Better palliative care for older people. Geneva (CH): WHO; 2004.

2. Jeyasingam L, Agar M, Soares M, Plummer J, Currow DC. A prospective study of unmet activity of daily living needs in palliative care inpatients. Aust Occup Ther J. 2008 Dec; 55(4):266-72.

3. Stabenau HF, Morrison LJ, Gahbauer EA, Leo-Summers L, Allore HG, Gill TM. Functional trajectories in the year before hospice. Ann Fam Med. 2015;13(1):33-40.

4. Andrade SMG. A perda de autonomia em doentes paliativos com cancro do pulmão [dissertação]. Lisboa (PT): Universidade de Lisboa; 2009.

5. Javier NS, Montagnini ML. Rehabilitation of the hospice and palliative care patient. J Palliat Med. 2011; 14(5):638-48.

6. Monteiro DR, Kruse MHL, Almeida MA. Avaliação do instrumento Edmonton Symptom Assessment System em cuidados paliativos: revisão integrativa. Rev Gaúcha Enferm. 2010; 31(4):785-93

7. Whittemore R, Knafl K. The integrative review: updated methodology. J Adv Nurs. 2005; 52(5):546-53.

8. Pompeo DA, Rossi LA, Galvão CM. Revisão integrativa: etapa inicial do processo de validação de diagnóstico de enfermagem. Acta Paul Enferm. 2009; 22(4):434-8.

9. Hastings C, Fisher CA. Searching for proof: Creating and using an actionable PICO question. Nurs Manage. 2014; 45(8):9-12.

10. Moher D, Liberati A, Tetzlaff J, Altman DG. Preferred reporting items for systematic reviews and meta- 
analyses: the PRISMA statement. Ann Intern Med. 2009; 151(4):264-9.

11. National Cancer Institute. Levels of Evidence for Supportive an Palliative Care Studies [Internet]. Bethesda: NCI; 2010 [cited 2014 Jul 01]. Available from: http://www.cancer.gov/cancertopics/pdq/ levels-evidence-supportive-care/HealthProfessional

12. Buss T, Walden-Galuszko K, Modlinska A, Osowicka M, Lichodziejewska-Niemierko M, Janiszewska J. Kinesitherapy alleviates fatigue in terminal hospice cancer patients-an experimental, controlled study. Support Care Cancer. 2010; 18(6):743-9.

13. Cheville AL, Kollasch J, Vandenberg J, Shen T, Grothey A, Gamble G, et al. A home-based exercise program to improve function, fatigue, and sleep quality in patients with Stage IV lung and colorectal cancer: a randomized controlled trial. J Pain Symptom Manage. 2013; 45(5):811-21.

14. Clemens KE, Jaspers B, Klaschik E, Nieland P. Evaluation of the clinical effectiveness of physiotherapeutic management of lymphoedema in palliative care patients. Jpn J Clin Oncol. 2010; 40(11):1068-72.

15. Granda-Cameron C, DeMille D, Lynch MP, Huntzinger C, Alcorn T, Levicoff J, et al. An interdisciplinary approach to manage cancer cachexia. Clin J Oncol Nurs. 2010; 14(1):72-80.

16. Gulde I, Oldervoll LM, Martin C. Palliative cancer patients' experience of physical activity. J Palliat Care. 2011; 27(4):296-302.

17. Guo Y, Shin KY, Hainley S, Bruera E, Palmer JL. Inpatient rehabilitation improved functional status in asthenic patients with solid and hematologic malignancies. Am J Phys Med Rehabil. 2011; 90(4):26571.

18. Henke CC, Cabri J, Fricke L, Pankow W, Kandilakis $\mathrm{G}$, Feyer PC, et al. Strength and endurance training in the treatment of lung cancer patients in stages IIIA/ IIIB/IV. Support Care Cancer. 2014; 22(1):95-101.

19. Jensen $W$, Baumann FT, Stein A, Bloch W, Bokemeyer $\mathrm{C}$, de Wit M, et al. Exercise training in patients with advanced gastrointestinal cancer undergoing palliative chemotherapy: a pilot study. Support Care Cancer. 2014; 22(7):1797-806

20. Jensen W, Bialy L, Ketels G, Baumann FT, Bokemeyer C, Oechsle K. Physical exercise and therapy in terminally ill cancer patients: a retrospective feasibility analysis. Support Care Cancer. 2014; 22(5):1261-8.

21. Jones L, Fitzgerald G, Leurent B, Round J, Eades J, Davis $S$, et al. Rehabilitation in advanced, progressive, recurrent cancer: a randomized controlled trial. J Pain Symptom Manage. 2013; 46(3):315-25.e3.

22. Kasven-Gonzalez N, Souverain R, MialeS. Improving quality of life through rehabilitation in palliative care: case report. Palliat Support Care. 2010; 8(3):359-69.

23. Litterini AJ, Fieler VK, Cavanaugh JT, Lee JQ.
Differential effects of cardiovascular and resistance exercise on functional mobility in individuals with advanced cancer: a randomized trial. Arch Phys Med Rehabil. 2013; 94(12):2329-35.

24. Maddocks M, Gao W, Higginson IJ, Wilcock A. Neuromuscular electrical stimulation for muscle weakness in adults with advanced disease. Cochrane Database Syst Rev. 2013; 1:CD009419

25. Oechsle K, Jensen W, Schmidt T, Reer R, Braumann KM, de Wit M, et al. Physical activity, quality of life, and the interest in physical exercise programs in patients undergoing palliative chemotherapy. Support Care Cancer. 2011; 19(5):613-9.

26. Oldervoll LM, Loge JH, Lydersen S, Paltiel H, Asp MB, Nygaard UV, et al. Physical exercise for cancer patients with advanced disease: a randomized controlled trial. Oncologist. 2011; 16(11):1649-57.

27. Saarik J, Hartley J. Living with cancer-related fatigue: developing an effective management programme. Int J Palliat Nurs. 2010; 16(1):6, 8-12.

28. Selman LE, Williams J, Simms V. A mixed-methods evaluation of complementary therapy services in palliative care: yoga and dance therapy. Eur J Cancer Care. 2012; 21(1):87-97.

29. Sturm I, Baak J, Storek B, Traore A, Thuss-Patience P. Effect of dance on cancer-related fatigue and quality of life. Support Care Cancer. 2014; 22(8):2241-9.

30. van Dam van Isselt EF, Groenewegen-Sipkema KH, Spruit-van Eijk M, Chavannes NH, Achterberg WP. Geriatric rehabilitation for patients with advanced COPD: programme characteristics and case studies. Int J Palliat Nurs. 2013; 19(3):141-6.

31. Jordhoy MS, Inger Ringdal G, Helbostad JL, Oldervoll L, Loge JH, Kaasa S. Assessing physical functioning: a systematic review of quality of life measures developed for use in palliative care. Palliat Med. 2007; 21(8):673-82.

32. Economou D. Palliative care needs of cancer survivors. Semin Oncol Nurs. 2014; 30(4):262-7.

33. Eyigor $S, A k d e n i z S$. Is exercise ignored in palliative cancer patients? World J Clin Oncol. 2014; 5(3):554-9.

34. Eyigor S. Physical activity and rehabilitation programs should be recommended on palliative care for patients with cancer. J Palliat Med. 2010; 13(10):1183-4.

35. Barawid E, Covarrubias N, Tribuzio B, Liao S. The benefits of rehabilitation for palliative care patients. Am J Hosp Palliat Care. 2015; 32(1):34-43.

36. Corsonello A, Scarlata S, Pedone C, Bustacchini S, Fusco S, Zito A, et al. Treating COPD in older and oldest old patients. Curr Pharm Des. 2015; 21(13):167289.

37. Osborne TR, Ramsenthaler C, Wolf-Linder S, Schey SA, Siegert RJ, Edmonds PM, et al. Understanding what matters most to people with multiple myeloma: a qualitative study of views on quality of life. BMC Cancer. 2014; 14(1):496. 
38. Cardoso DH, Muniz RM, Schwartz E, Arrieira ICO. Hospice care in a hospital setting: the experience of a multidisciplinary team. Texto Contexto Enferm. 2013 [cited 2015 Jan 23]; 22(4):1134-41 Anvailable from: http://www.scielo.br/scielo.php?script=sci_arttext\&pid=S0104-07072013000400032\&lng=en\&nrm=iso 